\title{
PENGARUH JENIS KELAMIN DAN LATAR BELAKANG SEKOLAH TERHADAP TOLERANSI PERBEDAAN MAZHAB FIQH
}

\author{
Abbas Arfan dan Fariz Zul Fahmi \\ Fakultas Syariah UIN Maulana Malik Ibrahim Malang \\ Emil:arfanbaraja@yahoo.com
}

\begin{abstract}
Abstrak
This quantitative research is to measure the quantity of tolerance attitude value in responding the difference tendency in affiliating school of thoughts (madzhab) among youths especially university students. This research is quantitative research which applies survey method, probability sampling-simple random sampling data collection technique, skala Likert instrument and theta formula analysis technique. The result shows two main findings; 1) there is no significant relationship between sex and tolerance attitude toward school of thought affiliation among university students. However, female students are more tolerant than male students.2) there is no significant relationship between school background and tolerant attitude towards school of thought affiliation among students. By contrast, non-islamic senior high school graduates are more tolerant than those Islamic senior high school graduates.

Penelitian ini berusaha mengukur secara kuantitas nilai sikap toleransi dalam menyikapi perbedaan mazhab figh terutama bagi generasi muda seperti mahasiswa. Jenis penelitian ini adalah kuantitatif dengan metode survey, teknik pengambilan datanya dengan probability sampling-simple random sampling, instrumen penelitiannya dengan model skala Likert dan teknik analisis datanya dengan rumus theta yang diuji dengan uji hipotesis chi-square. Hasil penelitian ini adalah (1) Tidak ada hubungan yang signifikan antara perbedaan jenis kelamin dengan sikap toleransi bermazhab figh mahasiswa. Namun mahasiswa dengan jenis kelamin perempuan lebih toleran daripada laki-laki, (2) Tidak ada hubungan yang signifikan antara perbedaan latar belakang sekolah dengan sikap toleransi bermazhab figh mahasiswa. Namun mahasiswa dari latar belakang sekolah non Madrasah Aliyah (MA) lebih toleran dari yang $M A$.
\end{abstract}

Kata kunci: Toleransi, Perbedaan Madzhab, Jenis Kelamin.

Persoalan perbedaan (khilafiyah) dalam mazhab fiqh sampai saat ini masih sering menjadi penyebab kerenggangan hubungan ukhuwah islamiyah antara sesama muslim Indonesia. Penyebab tersebut antara lain seperti bacaan Fatihah dalam shalat dengan basmalah atau tidak, shalat shubuh dengan qunut atau tidak, hukumnya tahlil dan talqin, shalat tarawih dengan 20 atau 8 rakaat dan lain-lain yang pada umumnya berkaitan dengan ubudiyah (ibadah). Perbedaan-perbedaan itu di tataran masyarakat bawah meruncing menjadi perselisihan dan fanatisme golongan, sehingga ada masjid A milik kelompok A dan masjid B milik golongan B, ada ulama golongan $A$ dan ulama kelompok B, bahkan ada Islam A, Islam B, Islam C, dan masih banyak lagi dikotomi-dikotomi yang 
menjurus kepada perpecahan umat Islam Indonesia. seperti kasus terbaru (tahun 2010) yang terjadi wilayah Bangil Pasuruan Jawa Timur yaitu konflik dan perseteruan antar mazhab ahl al-Sunnah wa al-Jama'ah (aswaja) dan Syi' ah yang telah menjadi ajang pertarungan fisik antar kedua kelompok sehingga mengakibatkan korban luka-luka dari keduanya. Jika konflik antar mazhab ini terus dibiarkan sehingga tidak lagi ada sikap toleransi bermazhab fiqh antar umat Islam Indonesia, maka secara perlahan namun pasti apa yang terjadi di Iraq, Pakistan, atau negara Islam lainnya akan juga terjadi di Indonesia, yaitu "penghalalan darah dan harta muslim dari mazhab fiqh yang berbeda", sehingga seorang muslim Sunni Iraq rela membawa bom bunuh diri dengan menyamar menjadi Syiah dan shalat di masjid Syi' ah dan juga sebaliknya. Sehingga kita bisa menggambarkan rendahnya sikap toleransi bermazhab fiqh masyarakat muslim Indonesia. Hal ini telah lama menjadi perhatian penulis, sehingga penulis terdorong untuk meneliti masalah ini dengan mengajak salah seorang mahasiswa syariah, maka lahirlah proposal penelitian ini yang berjudul; "Pengaruh Jenis Kelamin dan Latar Belakang Sekolah Terhadap Sikap Toleransi Perbedaan Mazhab Fiqh Mahasiswa Semester Dua Fakultas Syariah Universitas Islam Negeri Maulana Malik Ibrahim Malang Angkatan 2010/2011."

Rumusan masalah dalam penelitian ini adalah sebagai berikut; (1) Adakah hubungan antara jenis kelamin dengan sikap toleransi bermazhab figh mahasiswa semester dua Fakultas Syariah Universitas Islam Negeri Maulana Malik Ibrahim (Maliki) angkatan 2010/2011, (2) Adakah hubungan antara latar belakang sekolah dengan sikap toleransi bermazhab fiqh mahasiswa semester dua Fakultas Syariah Universitas Islam Negeri Maulana Malik Ibrahim (Maliki) angkatan 2010/2011.

Penelitian ini dibatasi pada dua variabel bebas saja, yaitu jenis kelamin (antara lakilaki dan permpuan) dan latar belakang asal sekolah menengah atas (antara Madrasah aliyah dan Non Madrsah Aliyah, seperti SMA dan SMK) sebelum masuk universitas untuk diteliti pengaruh keduanya dengan satu variabel terikat, yaitu sikap toleransi bermazhab fiqh mahasiswa semester dua Fakultas Syariah Universitas Islam Negeri Maulana Malik Ibrahim (Maliki) angkatan 2010/2011.

Tujuan dari penelitian ini adalah untuk mengetahui ada atau tidaknya hubungan dan pengaruh antara jenis kelamin dan latar belakang sekolah terhadap sikap toleransi bermazhab fiqih mahasiswa semester dua fakultas Syariah Universitas Islam Negeri Maulana Malik Ibrahim (Maliki) angkatan 2010/2011 dan dapat dijadikan dasar kebijakan tingkat universitas atau fakultas dalam membuat rumusan kurikulum materi pendidikan pluralisme mazhab fiqh (Figh alMuqâran) bagi mahasiswa perguruan tinggi atau pesantren dan madrasah aliyah seluruh Indonesia, baik sebagai kurikulum yang independent dalam matapelajarannya atau include dalam salah satu matapelajaran fiqh yang telah ada.

Perbedaan Mazhab Fiqh;Perbedaan dalam bahasa Arab dikenal dengan kata Ikhtilâf atau khilâf. Perbedaan pendapat dalam fiqh merupakan perbedaan yang disebabkan oleh perbedaan akal pikiran, karena bila ditinjau dari sebab-musabbabnya secara global, perbedaan itu di bagi dua, yaitu perbedan yang disebabkan budi pekerti (moral) dan perbedaan yang disebabkan akal pikiran. Perbedaan yang disebabkan moral itu biasanya dikarenakan terlalu menganggap cukup dengan melihat permukaan suatu masalah saja dan tidak mau mendalami dengan seksama dan teliti, seperti $s \hat{u}^{\prime} u$ dhan dengan orang lain, fanatik buta terhadap pendapat seseorang atau mazhab dan golongan tertentu. Ini tergolong ikhtilâf yang tercela. ${ }^{1}$

Perbedaan dalam fiqh merupakan sesuatu yang pasti terjadi, karena merupakan tabiat

${ }^{1}$ Yusuf al-Qardlâwî, Al-Shahwah al-Islamiyyah: bain al-Ikhtilâf al-Masyrûu wa Tafarruq al-Madzmûm, cet. V (Cairo: Dar al-Shohwah). h. 15-16. 
agama, bahasa, manusia juga alam dan kehidupan. Oleh karena itu orang-orang yang menghendaki bersatunya semua orang dalam satu pendapat di bidang hukumhukum ibadah, muamalah, dan lain-lain dari cabang-cabang agama (Islam), maka berarti ia menginginkan sesuatu yang mustahil terjadi. $^{2}$

Ikhtilâf fiqhî ini tidak hanya dianggap sebagai hal yang lazim dan rahmat, namun juga bisa merupakan harta karun warisan yang amat berharga, karena perbedaan pendapat para ulama adalah peninggalan yang bisa dijadikan bahan kajian bagi perkembangan figh itu sendiri di masa-masa mendatang, juga bahan pertimbangan dan masukan yang tidak sedikit nilainya. Namun sayang, kenyataan empiris di masyarakat luas belum bisa menjadikan perbedaan mazhab fiqh sebagai rahmat, tapi sebaliknya; sering menjadi azab dan titik awal perselisihan dan permusuhan antar sesama umat Islam sendiri dan klaim bahwa hanya ia dan kelompoknya atau mazhab fiqh-nya yang benar. Dengan kata lain, masyarakat Islam Indonesia pada umumnya belum bisa bersikap toleransi kepada golongan mazhab fiqh lainnya. Sebagaimana contoh perselisihan yang terdapat dalam latar belakang penelitian ini. ${ }^{3}$

Perspektif Toleransi; Istilah toleransi dalam bahasa Latin, disebut tolerare, yang bisa berarti menahan diri, membiarkan orang berpendapat, berhati lapang terhadap pandangan orang lain. sikap toleransi tidak berarti membenarkan pandangan atau aliran yang dibiarkan tersebut, akan tetapi mengakui kebebasan serta hak asasi penganutnya . ${ }^{4}$

Kamus teologi karya Gerald O'Collin \& Edwarrd G. Farrugia, menyebutkan toleransi berarti "membiarkan dalam damai orangorang yang mempunyai keyakinan dan praktek hidup yang lain". Sementara Kamus Besar

${ }^{2}$ Ibid., h. 59.

${ }^{3}$ al-Qardlawî,al-Shahwah... h. 78; al-Syatibi, "alI'itisham" (CD al-Maktabah al-Syamilah I), Juz I, h 413.

${ }^{4}$ Basuki Ismael dan (ed) Benyamin Molan, Negara Hukum Demokrasi Toleransi: Telaah Filosofis Atas John Locke(Jakarta: Intermedia,1993), h. 89.
Bahasa Indonesia, menyebutkan kata toleran berarti "bersifat atau bersikap menenggang (menghargai, membiarkan, membolehkan) pendirian (pendapat, pandangan, kepercayaan, kebiasaan, kelakukan, dan sebagainya.) yang berbeda atau bertentangan dengan pendirian sendiri." ${ }^{5}$

Bila ditilik secara etimologi, kata toleransi bermakna sifat atau sikap menenggang (menghargai, membiarkan, membolehkan) pendirian (pendapat, pandangan, kepercayaan, kebiasaan, kelakuan dan sebagainya) yang berbeda atau bertentangan dengan pendirian sendiri. ${ }^{6}$ Namun bila dilihat dari sisi terminologi budaya, sosial dan politik, toleransi berarti simbol kompromi beberapa kekuatan yang saling tarik-menarik atau saling berkonfrontasi untuk kemudian bahumembahu membela kepentingan bersama, menjaganya dan memperjuangkannya. Dalam konteks ini toleransi berarti juga kerukunan sesama warga negara dengan saling menenggang berbagai perbedaan yang ada di antara mereka. ${ }^{7}$

Peter Nicholson juga secara tidak langsung melihat bahwa toleransi adalah hal yang berkaitan dengan pilihan moral, dan rasa suka kita serta kecenderungan yang menyimpang. Menurutnya kesatuan perasaan tentang yang disukai ataupun tidak disukai menjadi hal yang digunakan untuk menghitung ketika seseorang memutuskan dan menjelaskan mengapa mereka toleran atau sebaliknya. Perasaan tersebut tidak secara moral mendasari dan tidak bisa menjadi dasar dari posisi moral seseorang. ${ }^{8}$

Dalam konsep Max Weber, toleransi harus dikaitkan dengan kesadaran dan penerimaan seseorang dalam mensikapi perbedaan kepercayaan yang dianutnya. Itu tidak salah,

\footnotetext{
${ }^{5}$ Kamus Teologi Karya Gerald O'Collin \& Edwarrd G. Farrugia

${ }^{6}$ W.J.S. Poerwadarminta. Kamus Besar Bahasa Indonesia Edisi II, (Jakarta: Balai Pustaka, 1985).

${ }^{7}$ Admon, "Toleransi Agama" (http:/alghuroba.org/ index.php, 2008)

${ }^{8}$ Dikutip dari tulisan Mary Warnock yang berjudul The Limits of Toleration dalam buku On Tolerantion, edited by Susan Mendus and David Edwards (Clarendon Press Oxford,1987), h. 126.
} 
tetapi konsep itu mestinya sekarang ditambah. Adalah benar, ketika seseorang dapat menerima orang lain yang berbeda kepercayaan dengan dirinya. Maka hal-hal lain yang bersifat kemasyarakatan pasti dia bisa menerimanya juga. Dikatakannya, kasus Indonesia sebenarnya berbeda, kita sudah mengenal apa yang namanya toleransi jauh sebelum kita menjadi bangsa Indonesia. Ketika masa kerajaan-kerajaan nusantara, yang namanya toleransi sudah ada, justeru ketika Max Weber belum lahir. Konsepsi Bhinneka Tunggal Ika, merupakan wujud nyata dari yang namanya toleransi. Toleransi yang ada sat itu tidak hanya menyangkut masalah agama, sebab kenyataannya hal tersebut merupakan cita-cita para pemimpin kerajaan akan adanya suatu negara yang besar pada masa mendatang di mana perbedaan-perbedaan itu bukan menjadi suatu ancaman tetapi suatu kekuatan. Perbedaan menjadi suatu rahmat.Konsepsi itu adalah konsep dari suatu sistem politik yang pluralis, yang menerima masyarakat multikultural seperti Indonesia ini.

Dalam perspektif agama, toleransi paling banyakmendapatkanperhatian.Katatolerance sebagai sebuah istilah muncul dalam bahasa Inggris saat terjdinya perang agama pada abad ke-16 Masehi antara penganut Protestan dan Katholik yang memaksa lahirnya praktik toleransi satu sama lain. Terma toleransi pada awalnya mengandung pengertian negatif, namun image negatif itu semakin berkurang dan bahkan akhirnya berkembang menjadi sebuah gagasan yang positif. Sebagai sebuah konsep dan teori, terma toleransi kemudian digunakan dalam bidang-bidang politik, agama, dan kepercayaan.

Interpretasi negatif (negative interpretation of tolerance) menyatakan, bahwa toleransi itu hanya menyaratkan cukup dengan membiarkan dan tidak menyakiti orang atau kelompok lain. Sedangkan penafsiran positif (positive interpretation of tolerance) mengatakan, bahwa toleransi memerlukan lebih dari itu, yaitu memerlukan bantuan, pertolongan, dan pembinaan ( pengertian toleran yang positif). Namun pengertian toleran yang positif ini hanya diperlukan pada satu situasi di mana sasaran dari toleransi adalah sesuatu yang moral tidak dianggap salah dan yang tidak dapat diubah, seperti dalam kasus toleransi rasial. Toleransi tidak hanya berkaitan dengan legislasi, tetapi juga sikap sosial. Dewasa ini hanya sedikit deskriminasi dan perilaku tidak toleran terhadap legislasi tersebut, tetapi sikap tidak toleran di antara individu atau kelompok masih muncul dalam banyak kasus, baik sebagai akibat dari motivasi ras, ideologi, politik maupun agama. ${ }^{9}$

Ada modal utama yang dibutuhkan untuk membangun toleransi sebagai nilai kebajikan, pertama, toleransi membutuhkan interaksi sosial melalui percakapan dan pergaulan yang intensif, kedua, membangun kepercayaan di antara pelbagai kelompok dan aliran (mutual trust). Inggris merupakan salah satu contoh negara yang menerapkan cara terbaik dalam membangun toleransi dengan menumbuhkan semangat kesatuan yang dibangun di atas pilar kebangsaan. Keberhasilan Inggris menginspirasikan bahwa membangun toleransi tidak hanya kuasa negara, tetapi juga kuasa nilai yang diterapkan secara sungguh-sungguh dalam sebuah negara. Proses toleransi tidak langsung jadi, melainkan kehadiran nilai yang mengakar kuat di tengah masyarakat, khususnya melalui perjumpaan dan dialog untuk membangun saling percaya. ${ }^{10}$

Adapun menurut Deklarasi Prinsip-Prinsip Toleransi UNESCO, toleransi adalah rasa hormat, penerimaan, dan penghargaan atas keragaman budaya dunia yang kaya, berbagai bentuk ekspresi diri, dan caracara menjadi manusia. Toleransi adalah kerukunan dalam perbedaan. ${ }^{11}$

Arus globalisasi menjadikan masalah ini bertambah rumit dan akut. Kaum pendatang

\footnotetext{
${ }^{9}$ Nur Achmad, Pluralitas Agama: Kerukunan dalam Keragaman, (Jakarta: Kompas, 2001), h. 13

${ }^{10}$ Zuhaeri Misrawi, Toleransi sebagai Kuasa Nilai, (Kompas 28 Mei 2008)

${ }^{11}$ Christelle Sadeghi dan Josiane Bechara Pandangan Kaum Muda; Dua Wajah Toleransi, dalam (www. commongroundnews.org/article), h. 4.
} 
dapat mempersoalkan masalah dominn identitas yang selama ini telah mempersatukan negara-bangsa dan menjungkirbalikan posisi serta relasasi/hubungan mayoritasminoritas. Arus globalisasi dan modernisasi membuat semakin banyaknya orang mengalami dengan percepatan teknologi komunikasi dan transportasi yang sangat cepat, sehinggan mengakibatkan identitas fragmen-fragmen yang bercerai-berai dari ikatan-ikatan lama yang semakin hilang, tanpa kemungkinan menjadikan rangkaian fragmen itu sesuatu yang utuh lagi. Jika hal tersebut terus dibiarkan, hasilnya adalah suatu identitas yang fragmentaris, yang dipersatukan hanya oleh garis sambung, $a$ hyphenated identities.

Hubungan Sikap Toleransi dengan Jenis Kelamin dan Latar Belakang Sekolah; Dalam ilmu biologi dan psikologi dikatakan bahwa dari penampilan fisik dan sikap perbuatan yang bersifat kodrat Ilahi itu telah menyimpulkan bahwa jenis kelamin (sex) perempuan lebih lembut dan halus daripada jenis kelamin laki-laki. Sehingga secara fitrah perempuan tidak suka konflik, kekerasan dan sejenisnya dan berbeda dengan laki-laki. Sedangkan rapuhnya toleransi bisa berakibat pada konflik dan perseteruan.

Karena gender adalah perbedaan peran, fungsi, dan tanggungjawab antara laki-laki dan perempuan yang merupakan hasil konstruksi sosial dan dapat berubah sesuai dengan perkembangan jaman. Sedangkan seks (jenis kelamin) adalah perbedaan jenis kelamin yang ditentukan secara biologis. Seks melekat secara fisik sebagai alat reproduksi. Oleh karena itu, seks merupakan kodrat atau ketentuan Tuhan sehingga bersifat permanen dan universal. Oleh karena itu perbedaan gender dan seks dapat dilihat tabel di bawah ini:
Adapun Hubungan sikap toleransi bermazhab fiqh dengan latar belakang pendidikan (sekolah) bisa juga berpengaruh secara positif atau negatif. Karena dalam sekolah yang diajarkan materi-materi agama Islam, terutama figh seperti Madarsah Aliyah (MA) seharusnya bisa menciptakan pribadi yang memiliki sikap baik terhadap toleransi bermazhab fiqh, namun bisa juga sebaliknya, karena bergantung pada meteri dan dogma yang diajarkan. Begitu juga sekolah umum, seperti Sekolah Menengah Atas (SMA), karena tidak banyak diajarkan materi-materi agama Islam selengkap dan sebanyak di MA itu bisa menjadikan mereka tidak punya sikap toleransi bermazhab fiqh yang baik, namun mungkin bisa sebaliknya.

Dalam penelusuran penulis, masih sedikit penelitian bahkan belum penulis temukan yang semisal dengan penelitian ini. Walau ada beberapa buku yang merupakan hasil penelitian terkait pencarian asal-muasal (geneologi) terjadinya perbedaan mazhab figh dengan pendekatan sejarah dari mulai zaman Nabi Muhammad SAW, para sahabat Nabi SAW dan para imam mazhab fiqh sampai masuknya Islam dan mazhab fiqh ke Indonesia, yaitu buku yang ditulis oleh Abbas Arfan dengan judul "Geneologi Pluralitas Mazhab dalam Hukum Islam." Namun penelitian dalam buku itu adalah studi pustaka ${ }^{12}$ dan normatif, sedangkan penelitian ini adalah studi empiris dengan jenis penelititan kuantitatif yang lebih fokus pada pemahaman umat Islam terhadap keberadaan nilai-nilai pluralitas mazhab figh dalam berukhuwah Islamiyah dalam sebuah komunitas masyarakat kampus yang plural mazhab fiqh sebagai populasi, di

${ }^{12}$ Baca Abbas Arfan, Geneologi Pluralitas Mazhab Dalam Hukum Islam, (Malang: UIN Malang Press, 2008)

\begin{tabular}{ll}
\hline \multicolumn{1}{c}{ Gender } & \multicolumn{1}{c}{ Seks / Jenis Kelamin } \\
\hline Bisa berubah & Tidak bisa berubah \\
\hline Dapat dipertukarkan & Tidak dapat dipertukarkan \\
\hline Tergantung musim & Berlaku sepanjang masa \\
\hline Tergantung budaya masing-masing & Berlaku di mana saja \\
\hline Bukan kodrat (buatan masyarakat) & Kodrat (ciptaan Tuhan, seperti hamil dII) \\
\hline
\end{tabular}


mana masyarakat Islam kampus khususnya Fakultas Syariah menjadi miniatur bagi masyarakat Islam yang ada di luar kampus. Maka penelitian ini merupakan lanjutan dan pengembangan dari penelitian normatifkualitatif kepada empiris-kuantitatif.

Kerangka berfikir yang terbentuk untuk sementara waktu adalah " jika jenis kelamin perempuan, maka lebih toleran dari lakilaki dan jika seseorang mahasiswa berlatar belakang sekolah yang banyak mempelajari agama Islam, yaitu madarasah aliyah maka lebih toleran dalam bersikap dalam menyikapi perbedaan mazhab fiqh yang ada di masyarakat daripada mahasiswa yang berlatar belakang pendidikan non madrasah aliyah. Oleh karena itu sikap toleransi bermazhab fiqh seorang mahasiswa akan semakin tinggi, jika ia berjenis kelamin perempuan dan tamatan madrasah aliyah".

Adapun hipotesis yang diajukan untuk sementara waktu adalah "ada hubungan dan pengaruh yang signifikan antara perbedaan jenis kelamin dan latar belakang sekolah dengan sikap toleransi bermazhab fiqh mahasiswa semester dua fakultas Syariah Universitas Islam Negeri Maulana Malik Ibrahim (Maliki) angkatan 2010/2011".

Karena rumusan penelitian ini bersifat asosiatif, yaitu menanyakan hubungan dan pengaruh antara dua variabel atau lebih, maka hepotesis statistaknya adalah:

Ho: $p=0$, berarti "sama dengan nol", maka hipotesisisnya adalah tidak ada hubungan.

Ha : $p \neq 0$, berarti "tidak sama dengan nol", maka bisa mungkin lebih besar atau kurang dari nol, sehingga hipotesisnya adalah ada hubungan. Dan p adalah nilai korelasi dalam formulasi yang dihipotesiskan.

\section{Metode Penelitian}

Jenis atau paradigma dari penelitian ini adalah kuantitatif, karena berusaha mengukur hubungan antara dua variabel secara kuantitas (angka-angka).Dan dalam dalam penelitian kuantitatif hanya memilki dua metode, yaitu eksperimen dan survey. Da- lam penelitian eksperimen ada perlakuan khusus (treatment), karena berusaha mencari pengaruh perlakuan tertentu terhadap yang lain dalam kondisi yang terkendalikan. Karena penelitian ini tidak akan melakuakan sebuah perlakuan khusus, maka metode penelitian ini adalah survey, yaitu murni pengamatan lapangan dengan mengumpulkan data-data kuantitatif untuk dianalisis, diuji dan diukur untuk kemudian disimpulkan secara kuantitif juga.

Penelitian ini dilaksanakan di Fakultas Syari'ah Universitas Islam Negeri Maulana Malik Ibrahim yang berlokasi di Jl. Gajayana 50 Malang yang dipimpin oleh Dekan Dr. Hj. Tutik Hamidah M.Ag. Sedangkan Rektornya adalah Prof. Dr. H. Imam Suprayogo.

Sedangkan waktu penelitian ini telah dilaksanakan pada semester genap tahun akademik 2010-2011 antara bulan Mei-Juli 2011. Instrumen keperluan penelitian ini cobakan telah diujicobakan sebelumnya pada pertengahan mei2011 dan pengumpulan data telah dilaksanakan akhir Mei-pertengahan Juni 2011. Sedangkan pengolahan data dan penulisan laporan penelitian dilakukan pada bulan Juni-Agustus 2011.

Populasi adalah wilayah generalisasi yang terdiri atas obyek/subyek yang mempunyai kualitas dan karekteristik tertentu yang di tetapkan oleh peneliti untuk dipelajari dan ditarik kesimpulannya. ${ }^{13}$ Dan dari segi kuntitas ada dua jenis pupulasi, yaitu populasi tertabas dan tidak terbatas (tak terhingga). Karena penelitian ini hanya akan meneliti mahasiswa semester dua fakultas Syariah UIN Maliki Malang angkatan 2010/2011 yang lebih kurang berjumlah 225 orang, maka populasi dalam penelitian ini adalah terbatas.

Sampel adalah bagian dari jumlah dan karekteristik yang dimiliki oleh populasi tersebut. ${ }^{14}$ Dan untuk menentukan sampel yang akan diambil dari populasi yang ada itu sangat ditentukan oleh teknik

\footnotetext{
${ }^{13}$ Sugiyono, Metode Penelitian Kuantitatif, Kualitatif dan RED. (Bandung: Alfabeta, 2009), h. 72.

${ }^{14}$ Ibid., h. 81.
} 
sampling. Secara general teknik sampling dibagi dua, yaitu: probability sampling dan nonprobability sampling. Probability sampling adalah teknik yang memberikan peluang yang sama bagi setiap unsur (anggota) populasi untuk dipilih menjadi anggota sampel. Sedangkan non probability sampling adalah sebaliknya. ${ }^{15}$ Maka penelitian ini menggunankan teknik pengambilan sampel dengan teknik probability sampling-simple random sampling. ${ }^{1}$ Yaitu sebuah teknik di mana semua anggota populasi mendapat peluang yang sama untuk dijadikan sampel, untuk kemudian dipilih secara acak dalam menentukan sampel yang akan diuji. Maka dalam penelitian ini akan diambil hanya 80 sampel saja dari total populasi yang ada (225), namun setelah sebelumnya terklasifikasi empat jenis sampel, yaitu jenis laki-laki dari MA dan non MA, jenis perempuan dari MA dan non MA dengan masing-masing jenis di ambil secara random lebih kurang 30 sampel, sehingga total sampel yang diambil adalah 120 sampel

Instrumen dalam penelitian ini menggunakan jenis pengukuran indeks adalah skala sikap model skalalikert, yaitu berisi pernyataan yang sistematis untuk menunjukkan sikap seorang responden terhadap pernyataan-pernyataan dalam angket tentang sikap toleransi perbedaan

\footnotetext{
${ }^{15}$ Ibid., h. 81-82.

${ }^{16}$ Ibid.
}

mazhab fiqh. Indeks ini mengasumsikan bahwa masing-masing kategori jawaban itu memiliki intensitas yang sama. Keunggulan indeks ini adalah kategorinya memilki urutan yang jelas mulai dari "sangat setuju", "setuju", "ragu-ragu", "tidak setuju" dan "sangat tidak setuju" dengan skor tertinggi bernilai lima (5) untuk "sangat setuju" untuk pernyataan positif dan sebaliknya; untuk pernyataan negatif skor tertinggi dengan nilai lima (5) untuk "sangat tidak setuju"17.

Teknik analisis data yang digunakan dalam penelitian ini adalah analisis statistik non parametrikuntuk menjawab rumusan masalah kesatu dan kedua.Maka teknis analisis untuk menjawab rumusan masalah kesatu dan kedua akan menggunakan perhitungan asosiasi Theta (q), yang bisa memprediksi ranking pada suatu variabel atas dasar kategori pada variabel lainnya. ${ }^{18}$ Karena Theta di gunakan untuk hubungan antara data nominal dan ordinal, maka variabel terikat (y) yang berupa nilai skala likert dari sikap toleransi bermazhab fiqh harus dirupakan skala ordinal dengan tiga tingkatan, yaitu tinggi (untuk nilai 111-150), sedang (untuk nilai 71-110) dan rendah (untuk nilai 30-70). Lihat Tabel di bawah.

Latar belakang pendirian Fakultas Sya-

${ }^{17}$ Bambang Prasetyo dan Lina Miftahul Jannah. Metode Penelitian Kuantitatif: Teori dan Aplikasi. (Jakarta: Rajawali Press, 2008), h. 110-111.

${ }^{18}$ Riduan dan Akdon, Rumus dan Data dalam Analisis Statistika (Bandung: Alfabeta, 2009), h. 95.

\begin{tabular}{|c|c|c|c|c|}
\hline No. & Jenis Variabel & Jenis Data & $\begin{array}{c}\text { Teknik Analisis } \\
\text { Data }\end{array}$ & Uji Hipotesis \\
\hline 1. & $\begin{array}{l}\text { Hubunganjeniskelamin } \\
\text { dengan sikap toleransi } \\
\text { perbedaanmazhabfiqh. }\end{array}$ & Nominal dengan Ordinal & $\begin{array}{l}\text { Theta }(\theta) \\
=\frac{\sum D_{i}}{T_{2}}\end{array}$ & $\begin{array}{c}\text { Chi-Square } \\
\left(\chi^{2}\right)=\frac{\sum(O-E)^{2}}{E}\end{array}$ \\
\hline 2. & $\begin{array}{l}\text { Hubungan Latar } \\
\text { belakang sekolah } \\
\text { dengan sikap toleransi } \\
\text { perbedaanmazhabfiqh. }\end{array}$ & Nominal dengan Ordinal & $\begin{array}{l}\text { Theta }(\theta) \\
=\frac{\sum D_{i}}{T_{2}}\end{array}$ & $\begin{array}{c}\text { Chi-Square } \\
\left(\chi^{2}\right)=\frac{\sum(O-E)^{2}}{E}\end{array}$ \\
\hline
\end{tabular}


riah adalah untuk memenuhi keinginan dan kebutuhan masyarakat terhadap pendidikan tinggi hukum Islam yang bertujuan memberikan bekal kepada calon sarjana mengenai hukum Islam, sehingga kelak setelah lulus mampu menerapkan dan mengembangkan di tengah masyarakat luas. Tujuan pendirian fakultas Syariah adalah untuk mencetak Ulama dan sarjana hukum Islam yang memiliki wawasan luas dan tidak ekstrim dalam memahami syariat Islam. Fakultas Syariah berdiri atas dasar keputusan Direktur Jenderal Kelembagaan Agama Islam Nomor: DJ.II/56/2005 tenang izin Penyelenggaraan Program Jenjang Strata Satu ( S-1) dan Diploma Dua (D2) pada Universitas Islam Negreri Maulana Malik Ibrahim (UIN Maliki) Malang. Pada Tahun 2007 Fakultas sayari'ah Membuka Program baru yakni Hukum Bisnis Syari'ah (HBS) dan jurusan ini memperoleh izin atas dasar keputusan direktur Jenderal Kelembagaan Agama Islam Nomer : j.I/ Dt.IV/H.005/70/2007. Sebenarnya, fakultas Syari'ah jurusan/program studi al-Ahwal alSyakhshiyyah dan Hukum Bisnis Syari'ah merupakan pengembangan dari jurusan Syari'ah Sekolah Tinggi Agama Islam Negeri
Sedangkan mahasiswa Fakultas Syari'ah UIN Maulana malik Ibrahim angkatan 2010/2011 berjumlah 225 orang; dengan rincian110Jurusanal-Ahwalal-Syakhshiyyah dan 105 Jurusan Hukum Bisnis Syari' ah.

Jika data-data diatas diolah lagi untuk dianalisis dengan lebih rinci sesuai dengan tiga rumusan masalah di atas, maka setiap upaya untuk menjawab setiap rumusan masalah diperlukan empat (4) langkah yang akan dijabarkan sebagai berikut:

Pertama; Hubungan Perbedaan Jenis Kelamin Dengan Sikap Toleransi; Langkah (1). Membuat Ha dan Ho dalam bentuk kalimat: Ha: Terdapat hubungan antara perbedaan jenis kelamin dengan sikap toleransi bermazhabfiqhmahasiswasemesterduaFakultas Syariah Universitas Islam Negeri Maulana Malik Ibrahim (Maliki) angkatan 2010/2011. Ho: Tidak ada hubungan antara perbedaan jenis kelamin dengan sikap toleransi bermazhab fiqh mahasiswa semester duaFakultas Syariah Universitas Islam Negeri Maulana Malik Ibrahim (Maliki) angkatan 2010/2011. Langkah (2). Membuat Ha dan Ho dalam bentuk statistik: Ha: $\varnothing \neq 0$ Ho: $\varnothing=0$ Langkah (3). Membuat tabel penolong untuk menghitung Theta:

\begin{tabular}{ccccc}
\hline \multirow{2}{*}{ Jenis Kelamin } & \multicolumn{4}{c}{ Tingkatan Sikap Toleransi } \\
\cline { 2 - 5 } & Tinggi & Sedang & Rendah & Jumlah \\
\hline Laki-laki & 22 & 17 & 1 & 40 \\
\hline Perempuan & 29 & 11 & 0 & 40 \\
\hline Jumlah & 51 & 28 & 1 & 80 \\
\hline
\end{tabular}

(STAIN) malang yang didirikan padatahun ajaran 1997/1998 berdasarkan keputusan Direktur Jendral Pembinaan Kelembagaan Islam Departemen Agama RI No: E/107/ tahun 1998 tanggal 13 Mei 1998.
Langkah 4. Menghitung Theta (Ø):

$\mathrm{F}_{\mathrm{b}}$ untuk perbandingan antara laki-laki dan perempuan sebagai berikut:

\begin{tabular}{|c|c|c|c|}
\hline & $T$ & $S$ & $R$ \\
\hline LK & 22 & & \\
\hline PR & & 11 & 0 \\
\hline
\end{tabular}

\begin{tabular}{|c|c|c|c|}
\hline & $\mathrm{T}$ & $\mathrm{S}$ & $\mathrm{R}$ \\
\hline LK & & 17 & \\
\hline PR & & & 0 \\
\hline
\end{tabular}

\begin{tabular}{|c|c|c|c|}
\hline & $\mathrm{T}$ & $\mathrm{S}$ & $\mathrm{R}$ \\
\hline LK & & & 1 \\
\hline PR & & & \\
\hline
\end{tabular}




$\begin{array}{lll}\text { Tinggi } & : 22(11+0) & =242 \\ \text { Sedang } & : 17(0) & =0 \\ \text { Rendah } & : \underline{1(0)} & =0 \\ & \text { Jumlah } & =242\end{array}+$

$\mathrm{F}_{\mathrm{a}}$ Untuk perbandingan antara laki-laki dan perempuan sebagai berikut:
Jadi, atas dasar perbandingan antara posisi kedudukan mahasiswa laki-laki dan mahasiswa perempuan adalah $1,8 \%$, di mana ternyata mahasiswa perempuan memiliki sikap toleransi lebih tinggi. Selanjutnya untuk menguji signifikansi antara kedua variabel akan dibahas dalam subbab

\begin{tabular}{|c|c|c|c|}
\hline & $\mathrm{T}$ & $\mathrm{S}$ & $\mathrm{R}$ \\
\hline LK & 22 & & \\
\hline $\mathrm{PR}$ & & & \\
\hline
\end{tabular}

\begin{tabular}{|c|c|c|c|}
\hline & $\mathrm{T}$ & $\mathrm{S}$ & $\mathrm{R}$ \\
\hline LK & & 17 & \\
\hline PR & 29 & & \\
\hline
\end{tabular}

\begin{tabular}{|c|c|c|c|}
\hline & T & S & R \\
\hline LK & & & 1 \\
\hline PR & 29 & 11 & \\
\hline
\end{tabular}

$\begin{array}{lll}\begin{array}{l}\text { Tinggi } \\ \text { Sedang }\end{array} & : 17(22) & =0 \\ \text { Rendah } & : 1(29+11) & =40 \\ & \text { Jumlah } & =533 \\ \mathrm{D}_{\mathrm{i}}=\left[\mathrm{F}_{\mathrm{b}}-\mathrm{F}_{\mathrm{a}}\right]=[242-533] & =291 \\ \mathrm{~T}_{2}=40 \times 40=1600 & \\ \text { Theta }(\varnothing)=\frac{\sum D_{i}}{T_{2}}=\frac{291}{1600}=0,18\end{array}$

Hasil analisis ini menginformasikan bahwa hubungan perbedaan jenis kelamin mahasiswa dengan sikap toleransi perbedaan mazhab fiqh sebesar 0,18 tergolong rendah. Kontribusinya sebesar $0,18^{2} \times 100 \%=3,24 \%$ dan sisanya $96,76 \%$ ditentukan variabel lain. Berdasarkan perhitungan Theta di atas, kita juga mampu mengurangi kesalahan menduga sebesar $1,8 \%$ dari hubungan antara perbedan jenis kelamin dengan sikap toleransi bermazhabfiqh mahasiswa berikutnya, yaitu: "D. Pengujian Hipotesis" setelah bagian ini selesai.

Kedua; Hubungan Perbedaan Latar Belakang Sekolah Dengan Sikap Toleransi, Langkah (1). Membuat Ha dan Ho dalam bentuk kalimat: Ha: Terdapat hubungan antara perbedaan latar belakang sekolah dengan sikap toleransi bermazhabfiqh mahasiswa semester duaFakultas Syariah Universitas Islam Negeri Maulana Malik Ibrahim (Maliki) angkatan 2010/2011. Ho: Tidak ada hubungann antara perbedaan latar belakang sekolah dengan sikap toleransi bermazhab fiqh mahasiswa semester dua Fakultas Syariah Universitas Islam Negeri Maulana Malik Ibrahim (Maliki) angkatan 2010/2011. Langkah (2). Membuat Ha dan Ho dalam bentuk statistik: Ha: $\varnothing \neq 0$ Ho: $\varnothing=0$ Langkah (3). Membuat tabel penolong untuk menghitung Theta:

\begin{tabular}{|c|c|c|c|c|}
\hline \multirow{2}{*}{ Latar Belakang Sekolah } & \multicolumn{4}{|c|}{ Tingkatan Sikap Toleransi } \\
\cline { 2 - 5 } & Tinggi & Sedang & Rendah & Jumlah \\
\hline Madrasah Aliyah & 24 & 16 & 0 & 40 \\
\hline Non Madrasah Aliyah & 27 & 12 & 1 & 40 \\
\hline Jumlah & 51 & 28 & 1 & 80 \\
\hline
\end{tabular}

semester duaFakultas Syariah Universitas Islam Negeri Maulana Malik Ibrahim (Maliki) angkatan 2010/2011.

\begin{tabular}{|c|c|c|c|}
\hline & $\mathrm{T}$ & $\mathrm{S}$ & $\mathrm{R}$ \\
\hline MA & 24 & & \\
\hline $\begin{array}{c}\text { Non } \\
\text { MA }\end{array}$ & & 12 & 1 \\
\hline
\end{tabular}

\section{Langkah 4. Menghitung Theta (Ø):}

$\mathrm{F}_{\mathrm{b}}$ untuk perbandingan antara Madrasah Aliyah (MA) dan non MA sebagai berikut:

\begin{tabular}{|c|c|c|c|}
\hline & $\mathrm{T}$ & $\mathrm{S}$ & $\mathrm{R}$ \\
\hline MA & & 16 & \\
\hline $\begin{array}{c}\text { Non } \\
\text { MA }\end{array}$ & & & 1 \\
\hline
\end{tabular}

\begin{tabular}{|c|c|c|c|}
\hline & T & S & R \\
\hline MA & & & 0 \\
\hline Non & & & \\
MA & & & \\
\hline
\end{tabular}




$\begin{array}{lll}\text { Tinggi } & : 24(12+1) & =312 \\ \text { Sedang } & : 16(1) & =16 \\ \text { Rendah } & : \underline{0(0)} & =0 \\ & \text { Jumlah } & =328\end{array}+$

$\mathrm{F}_{\mathrm{a}}$ Untuk perbandingan antara Madrasah Aliyah (MA) dan non MA sebagai berikut:

\begin{tabular}{|c|c|c|c|}
\hline & T & S & R \\
\hline MA & 24 & & \\
\hline Non & & & \\
MA & & & \\
\hline
\end{tabular}

\begin{tabular}{|c|c|c|c|}
\hline & $T$ & $S$ & $R$ \\
\hline MA & & 16 & \\
\hline $\begin{array}{c}\text { Non } \\
\text { MA }\end{array}$ & 27 & & \\
\hline
\end{tabular}

\begin{tabular}{|c|c|c|c|}
\hline & $\mathrm{T}$ & $\mathrm{S}$ & $\mathrm{R}$ \\
\hline MA & & & 0 \\
\hline $\begin{array}{c}\text { Non } \\
\text { MA }\end{array}$ & 27 & 12 & \\
\hline
\end{tabular}

$4,2 \%$, di mana ternyata mahasiswa dengan latar belakang sekolah non MA memiliki sikap toleransi lebih tinggi. Selanjutnyauntuk menguji signifikansi antara kedua variabel akan dibahas dalam subbab di bawah ini.

$\begin{array}{lll}\begin{array}{l}\text { Tinggi } \\ \text { Sedang }\end{array} & : 24(0) & =0 \\ \text { Rendah } & : \underline{0(27+12)} & =0 \\ & \text { Jumlah } & =432 \\ \mathrm{D}_{\mathrm{i}}=\left[\mathrm{F}_{\mathrm{b}}-\mathrm{F}_{\mathrm{a}}\right]=[328-432] & =104 \\ \mathrm{~T}_{2}=40 \times 40=1600 & \end{array}$

$$
\operatorname{Theta}(\varnothing)=\frac{\sum D_{i}}{T_{2}}=\frac{104}{1600}=0,065
$$

Hasil analisis ini menginformasikan bahwa hubungan perbedaan latar belakang sekolah/pendidikan asal mahasiswa dengan sikap toleransinya sebesar 0,065 tergolong rendah. Kontribusinya sebesar $0,065^{2} \times 100 \%=0,42 \%$ dan sisanya $99,58 \%$ ditentukan variabel lain. Berdasarkan perhitungan Theta di atas, kita juga mampu mengurangi kesalahan menduga sebesar $4,2 \%$ dari hubungan antara perbedaan latar belakang sekolah dengan sikap toleransi bermazhabfiqh mahasiswa semester duaFakultas Syariah Universitas Islam Negeri Maulana Malik Ibrahim (Maliki) angkatan 2010/2011.

Jadi, atas dasar perbandingan antara posisi kedudukan mahasiswa dengan latar belakang sekolah MA dan non MA adalah

\section{Hubungan Perbedaan Jenis Kelamin Dengan Sikap Toleransi}

Untuk menguji signifikansi apakah kedua variabel ada hubungan yang signifikan atau tidak antara perbedaan jenis kelamin terhadap sikap toleransi bermazhabfiqh mahasiswa semester duaFakultas Syariah Universitas Islam Negeri Maulana Malik Ibrahim (Maliki) angkatan 2010/2011. Maka dapat diuji dengan dengan Chi-Square $\left(X^{2}\right)$ dengan rumus:

$$
\left(\mathbf{X}^{2}\right)=\frac{\sum(O-E)^{2}}{E}
$$

dimana : $\mathrm{O}=$ Frekwensi Observasi dan $\mathrm{E}=$ Frekwensi yang diharapkan.

Sedangkan untuk uji signifikansi ini melalui tiga (3) tahap langkah, yaitu sebagai berikut: Langkah (1). Membuat Ha dan Ho dalam bentuk kalimat: Ha: Terdapat hubungan yang signifikan antara perbedaan jenis kelamin dengan sikap toleransi bermazhabfiqh mahasiswa semester duaFakultas Syariah Universitas Islam Negeri Maulana Malik Ibrahim (Maliki) angkatan 2010/2011. Ho: Tidak ada hubungan yang signifikan antara perbedaan jenis kelamin dengan sikap toleransi bermazhab fiqh mahasiswa semester dua Fakultas Syariah Universitas Islam Negeri Maulana Malik Ibrahim (Maliki)

\begin{tabular}{|l|l|l|}
\hline$E_{a}=\frac{40 \times 51}{80}=25,5$ & $E_{c}=\frac{40 \times 28}{80}=14$ & $E_{e}=\frac{40 \times 1}{80}=0,5$ \\
\hline$E_{b}=\frac{40 \times 51}{80}=25,5$ & $E_{d}=\frac{40 \times 28}{80}=14$ & $E_{f}=\frac{40 \times 1}{80}=0,5$ \\
\hline
\end{tabular}


angkatan 2010/2011. Langkah (2). Menghitung Chi-Square $\left(X^{2}\right)$ :

Adapun tabel frekwensi yang diharapkan (E) dari hasil pengamatan $(\mathrm{O})$ untuk variabel jenis kelamin dengan sikap toleransi dapat dilihat pada tabel di bawah ini:

\section{Hubungan Perbedaan Latar Belakang Sekolah Dengan Sikap Toleransi}

Untuk menguji signifikansi apakah kedua variabel ada hubungan yang signifikan atau tidak antara perbedaan latar belakang sekolah terhadap sikap toleransi mahasiswa

\begin{tabular}{|l|l|l|l|l|l|}
\hline Sel & O & E & O-E & $(\mathrm{O}-\mathrm{E})^{2}$ & $\frac{\sum(O-E)^{2}}{E}$ \\
\hline A & 22 & 25,5 & $-3,5$ & 12,25 & 0,480392157 \\
\hline B & 29 & 25,5 & 3,5 & 12,25 & 0,480392157 \\
\hline C & 17 & 14 & 3 & 9 & 0,642857143 \\
\hline D & 11 & 14 & -3 & 9 & 0,642857143 \\
\hline E & 1 & 0,5 & 0,5 & 0,25 & 0,5 \\
\hline F & 0 & 0,5 & $-0,5$ & 0,25 & 0,5 \\
\hline \multicolumn{7}{|l}{$\mathbf{X}^{2}$ hitung } & 3,246498599 \\
\hline
\end{tabular}

Langkah (3). Membandingkan $\mathbf{X}^{2}$ hitung dengan $\mathbf{X}^{2}$ tabel:

$$
\begin{aligned}
(\mathrm{k}-1)(\mathrm{b}-1) \cdot 1 / 2 & =(3-1)(2-1) \cdot 1 / 2 \\
& =1
\end{aligned}
$$

sehingga didapat

$$
\mathbf{X}^{2} \text { tabel }=3,841
$$

Dasar pengambilan keputusan dengan membandingkan nilai $\mathbf{X}^{2}$ hitung dengan $\mathbf{X}^{2}$ tabel sebagai berikut:

Jika $\mathbf{X}^{2}$ hitung $>\mathbf{X}^{2}$ tabel, Ho ditolak artinya signifikan

Jika $\mathbf{X}^{2}$ hitung $<\mathbf{X}^{2}$ tabel, Ho diterima artinya tidak signifikan

Ternyata $\mathbf{X}^{2}$ hitung $<\mathbf{X}^{2}$ tabel, atau 3,246< 3,841, maka Ho diterima yang artinya tidak signifikan.Sehingga dapat disimpulkan bahwa tidak ada hubungan yang signifikan antara perbedaan jenis kelamin dengan sikap toleransi bermazhab fiqh mahasiswa semester dua Fakultas Syariah Universitas Islam Negeri Maulana Malik Ibrahim (Maliki) angkatan 2010/2011.
Fakultas Syari'ah UIN Maliki Malang angkatan 2010/2011. Maka dapat diuji dengan dengan Chi-Square $\mathbf{X}^{2}$ dengan rumus: $\left(\mathbf{X}^{2}\right)=\frac{\sum(O-E)^{2}}{E}$

dimana : $\mathrm{O}=$ Frekwensi Observasi dan $\mathrm{E}=$ Frekwensi yang diharapkan.

Sedangkan untuk uji signifikansi ini melalui tiga (3) tahap langkah, yaitu sebagai berikut: Langkah (1). Membuat $\mathrm{Ha}$ dan Ho dalam bentuk kalimat: Ha: Terdapat hubungan yang signifikan antara perbedaan latar belakang sekolah dengan sikap toleransi bermazhab fiqh mahasiswa semester dua Fakultas Syariah Universitas Islam Negeri Maulana Malik Ibrahim (Maliki) angkatan 2010/2011. Ho: Tidak ada hubungan yang signifikan antara perbedaan latar belakang sekolah dengan sikap toleransi bermazhab fiqh mahasiswa semester dua Fakultas Syariah Universitas Islam Negeri Maulana Malik Ibrahim (Maliki) angkatan 2010/2011. Langkah (2). Menghitung Chi-Square ( $\left.\mathrm{X}^{2}\right)$ : 


\begin{tabular}{|c|c|c|}
\hline$E_{a}=\frac{40 \times 51}{80}=25,5$ & $E_{c}=\frac{40 \times 28}{80}=14$ & $E_{e}=\frac{40 \times 1}{80}=0,5$ \\
\hline$E_{b}=\frac{40 \times 51}{80}=25,5$ & $E_{d}=\frac{40 \times 28}{80}=14$ & $E_{f}=\frac{40 \times 1}{80}=0,5$ \\
\hline
\end{tabular}

Adapun tabel frekwensi yang diharapkan (E) dari hasil pengamatan $(\mathrm{O})$ untuk variabel jenis kelamin dengan sikap toleransi adalah sebagai berikut: latar belakang sekolah dengan sikap toleransi bermazhab fiqh mahasiswa semester dua Fakultas Syariah Universitas Islam Negeri Maulana Malik Ibrahim (Maliki) angkatan 2010/2011.

\begin{tabular}{|l|l|l|l|l|l|}
\hline Sel & O & E & O-E & $(\mathrm{O}-\mathrm{E})^{2}$ & $\frac{\sum(O-E)^{2}}{E}$ \\
\hline A & 24 & 25 & -1 & 1 & 0,04 \\
\hline B & 27 & 25 & 2 & 4 & 0,16 \\
\hline C & 16 & 4,5 & 11,5 & 132,25 & 29,38889 \\
\hline D & 12 & 4,5 & 7,5 & 56,25 & 12,5 \\
\hline E & 0 & 0,5 & $-0,5$ & 0,25 & 0,5 \\
\hline F & 1 & 0,5 & 0,5 & 0,25 & 0,5 \\
\hline \multicolumn{7}{|l|}{$X^{2}$ hitung } & 43,08889 \\
\hline \multicolumn{7}{|l|}{ Dengan pembulatan } & 43,09 \\
\hline
\end{tabular}

Langkah (3). Membandingkan $X^{2}$ hitung dengan $\mathrm{X}^{2}$ tabel:

$(\mathrm{k}-1)(\mathrm{b}-1) \cdot 1 / 2=(3-1)(2-1) \cdot 1 / 2=1$ sehingga didapat $X^{2}$ tabel $=3,841$

Dasar pengambilan keputusan dengan membandingkan nilai $X^{2}$ hitung dengan $X^{2}$ tabel sebagai berikut:

Jika $X^{2}$ hitung $>X^{2}$ tabel, Ho ditolak artinya signifikan

Jika $X^{2}$ hitung $<X^{2}$ tabel, Ho diterima artinya tidak signifikan

Ternyata $X^{2}$ hitung $>X^{2}$ tabel, atau 43,09> 3,841, maka Ho ditolak yang artinya signifikan. Sehingga dapat disimpulkan bahwa ada hubungan yang signifikan antara perbedaan

\section{DAFTAR PUSTAKA}

Abd. Salâm, Abd. Wahâb, Thawîlah. 2000. "Atsar al-Lughah fi Ikhtilâf alMujtahidîn". Cairo: Dar al-Salâm

\section{Kesimpulan}

Penelitian ini menyimpulkan bahwa; pertama; Tidak ada hubungan yang signifikan antara perbedaan jenis kelamin dengan sikap toleransi bermazhab fiqh mahasiswa semester dua Fakultas Syariah Universitas Islam Negeri Maulana Malik Ibrahim (Maliki) angkatan 2010/2011. Kedua; Ada hubungan yang signifikan antara perbedaan latar belakang sekolah dengan sikap toleransi bermazhab fiqh mahasiswa semester dua Fakultas Syariah Universitas Islam Negeri Maulana Malik Ibrahim (Maliki) angkatan 2010/2011, yaitu Mahasiswa lulusan SMA lebih toleran dalam bermadzhab daripada mahasiswa lulusan Aliyah.

Al-'Alwanî, Thaha Jâbir Fayyâdh. 1422 H./ 2001 M. Adâb al-Ikhtilâf fi al-Islâm, terj. IjaSuntana, Etika Berbeda Pendapat dalam 
Islam. Bandung: Pustaka Hidayah

Arfan, Abbas. 2008. Geneonologi Pluralitas Mazhab Dalam Hukum Islam. Malang: UIN Press

Bin Hâmid, Shâleh bin Abdullah. 1415 H./ 1995 M. .Adâb al-Khilâf. Jeddah: alMajlis al-Islâmî al-'Alamî li al-Da 'wah wa al-Ighâtsah

Bisri, Cik Hasan. 2003. "Model Penelitian Fiqh, Jilid I", Bogor: Kencana

Bisri, Cik Hasan. 2002. "Pilar-Pilar Penelitian Hukum Islam Dan Pranata Sosial". Bandung: Lembaga Penelitian IAIN Sunan Gunung Djati

Ismael, Basuki dan (ed) Benyamin Molan.1993. Negara Hukum Demokrasi Toleransi: Telaah Filosofis Atas John Locke Jakarta: Intermedia.

Kasiram, Moh. 2008. Metodologi Penelitian. Malang: UIN Press

Al-Manâwî, Abd. Rauf. 1356 H. "Faidl alQâdir fi Syarh al-Jâmi al-Shagîr". Mesir: al-Maktabah al-Tijâriyyah al-Kubrâ

Nawâwî, Imâm. t.t. Al-Arba'în al-Nawâwiyyah, Surabaya: Bungkul Indah

Nawâwî, Imâm. t.t. Al-Minhâj fi Syarh Sahîh Muslim bin al-Hajjâj. AlMaktabah al-Syâmilah I.

Poerwadarminta, W.J.S. 1985. Kamus Besar Bahasa Indonesia Edisi II, Jakarta: Balai Pustaka

Prasetyo, Bambang dan Lina Miftahul Jannah. 2008. Metode Penelitian Kuantitatif: Teori dan Aplikasi. Jakarta: Rajawali Press.

Al-Qardlâwî, Yûsuf. 415 H./ 1995 M. alShahwah al-Islamiyyah: bain al-Ikhtilâf
al-Masyrûं wa Tafarruq al-Madhmûm. Kairo: Dar al-Shahwah

Qardlâwî, Yûsuf. 1415 H./ 1995 M. Fi Fiqhî al-Aulâwiyât: Dirâsah Jadîdah fi Dlau al-Qur'an wa al-Sunnah. Cairo-Mesir: Maktabah Al-Wahbah

Riduan dan Akdon. 2009. Rumus dan Data dalam Analisis Statistika. Bandung: Alfabeta.

Sya rânî, al-Imâm. 1409 M./ 1989 M. Al-Mizân al-Khadiriyyah. Cairo: Âlam al-Fikrî, cet.I.

Sya rânî, al-Imâm. t.t. al-Mizân al-Kubrâ, Semarang: Toha Putra

Sadeghi, Christelle dan Josiane Bechara Pandangan Kaum Muda; Dua Wajah Toleransi, dalam (www. commongroundnews.org/article),

Sucipto, Hery (editor). 2007. Islam Mazhab Tengah, Jakarta: Grafindo Khazanah Ilmu

Suwarno, Bambang. 2009. Rumus dan Data dalam Analisis Statistika, Bandung: Alfabeta, cet. III.

Sugiyono. 2009. Metode Penelitian Kuantitatif, Kualitatif dan RED. Bandung: Alfabeta, cet. VIII.

Trihendradi, Cornelius. 2009. Step by Step SPSS 16. Yogyakarta: Penerbit Andi.

al-Utsmanî, Abu Abdillah, Muhammad bin Abdurahman al-Dimasqî. (tanpa tahun). Rahmah al-Ummah fi Ikhtilâf alA'immah, Semarang: Toha Putra

Warnock, Mary.1987. The Limits of Toleration dalambukuOn Tolerantion, edited by Susan Mendus and David Edwards Clarendon Press Oxford. 